Article

\title{
The Harness of Intellectual Capital for Economic Progress and Sustainability
}

\author{
Irina Chiriac ${ }^{1 *}$, Gabriela Ignat ${ }^{2}$, George Ungureanu ${ }^{2}$, Dragoş Alexandru Robu ${ }^{2}$, \\ and Carmen Luiza Costuleanu ${ }^{2^{*}}$ \\ 1 Social Sciences and Humanities Research Department of Alexandru Ioan Cuza University, Iaşi, Romania \\ 2 University of Agricultural Sciences and Veterinary Medicine Ion Ionescu de la Brad, Iaşi, Romania \\ * Correspondence: irinaochiriac@yahoo.com; costuleanu.carmen@uaiasi.ro; Tel.: +40-745-357404
}

\begin{abstract}
Bio-economy is a major area of the strategy that must enable the European Union to achieve growth: smart, through the development of knowledge and innovation; and sustainable, based on a greener, more efficient economy in resource management. We believe that the progress of bio-economy cannot be achieved without the harnessing of intellectual capital. Our research aimed to emphasize the benefits of the dynamics of the intellectual capital growth on the evolution of the bio-economy. The aim of this analysis was to study the established link between the Energy Intensity of the Economy (EIE) and a number of factors that can measure the intellectual capital, such as: Market Capitalization of Bitcoin, Patent applications listed by European Patent Office and the Turnover from Innovation as a proportion of the total Turnover. The ultimate goal was represented by the generation of a regression model to see what factor influences mostly the progress of the bio-economy at European and Romanian level.
\end{abstract}

Keywords: intellectual capital; sustainability; harness; bio-economy; global crisis

\section{Introduction}

The global crisis that has given society a certain way of manifestation and behavior that is characteristic of emergencies, often defined by unbalanced strategic decisions, has a multidimensional character and includes aspects such as the crisis of the economic domain: energetic, financial, commercial; the crisis of the ecological and biosphere domain, environmental crisis [1-2].

The fundamental evolution that constantly required the development of the human race was based on solving the economic problem, meeting a growing set of needs, given the limited and insufficient resources. In the development of relationships between people and the environment in which they live, as part of nature, were structured diametrically opposite concepts, in analysis and vision. Knowledge of nature without wisdom has led to ignoring the risks of its alteration and to which attention is drawn today. The balance between man and the environment has been broken by technological progress, economic development and the demographic explosion. The law of action and reaction speaks its word. Albert Arnold Gore, the 45th Vice President of the USA, was talking about an environmental holocaust in what Karl Popper, considered to be one of the greatest science philosophers in the twentieth century, considers as an effect of disregarding nature namely the loss of the sense of piety for nature [3].

As long as the quality of human life depends on its natural environment of existence, the artificial environment created by people and the interrelationships between humans, the ecological crisis - an invisible bomb, manifests itself through violence on nature, including man, as in human hedonism on the account of nature, including on behalf of its neighbor [4].

The concept of "bio-economy", according to Bonaiuti, who used the concept at the end of the 1960s, represented an appropriate economic order that underpins all economic activities [5]. 
Georgescu-Roegen who has been studying economics since the 1970s had the same opinion. Essential in Georgescu-Roegen's research on bio-economics was his concern for economic growth without limitation that is incompatible with the fundamental laws of nature [6].

In one of his work, Enriquez argues that the application of genomics discoveries leads to a restructuring of the capacities of all companies and industries in a manner that will modify the world's economic condition. He highlighted the creation of a new economic sector, the "life sciences" [7].

The European Commission has begun to promote this concept a lot in recent years. One of the most important actors in this effort was Patermann, who was program director of "Biotechnology, Agriculture and Nutrition" at the European Commission's Directorate-General for Research, Science and Education. The first Global Bio-economic Summit took place in Berlin in December 2015. Globally, bio-economy has gained great significance in last years as a wide range of benefits have been detected by several countries [8].

Intellectual capital in the current economy becomes the new core of economic development, because the impact of financial assets and fixed assets is clearly inferior to the impact sustained by knowledge [9-10]. Reliable measurement of this one has become a major research area for practitioners and researchers since the early 1990s.

In recent decades, globalization has had a major impact on countries, institutions, businesses and individuals, which has led to the development of new technologies and processes [11]. Furthermore, given the impact that globalization has on the environment, appeared increasingly more concerns about sustainability issues. Thus, the notion of sustainability has become one of the most pressing challenges of our century, being a key word in global research and political agendas of the last decades [12]. There are many movements in this area, such as circular economy, the green economy and bioeconomy.

Progress in the field of bio-economy has become a priority objective of the European Union's research, development and innovation policy, coordinated by the principles of sustainability. The realization of this objective has the implicit purpose of developing the biotechnologies that can be used at macroeconomic and global level, so that the classical, high-cost resources are replaced by renewable resources of biological nature [13].

Ensuring the transfer of knowledge at an advanced and rigorous level will contribute to the exponential increase in the quality of human resources [14].

Consequently, the findings of the bioeconomy launches extensive evolutionary processes that require a comprehensive approach where knowledge economy plays a significant role [15].

Intellectual property is the currency of research and technology transfer today, particularly in the form of patents. The creation of research clusters alongside bioeconomic innovation is conditioned by the existence of quality universities. Collaboration between institutions and the economy increases the quality of innovation. The opportunity and mutual benefit of these collaborations is essential to bring real benefits [16].

The higher the number of patents of a university, the more they increase the chances of concluding contracts with businesses thus making it more efficient to exploit the innovative potential [17].

In the current "Universal Knowledge Network" [18], with a performance oriented culture [19], the high quality of intellectual capital can provide and motivate the improvement of human capital and the generation of new knowledge for the realization of a sustainable bio-economy.

In bioeconomy, knowledge is the most important intangible asset, and intellectual property is the currency of exchange. Creating value in knowledge depends on access to intellectual property rights [20].

Bioeconomy includes all the elements that determine the structure of intangible capital: intellectual property (copyright, software, patents, know-how, etc.), infrastructure (technologies and working procedures), human capital (employee skills and knowledge) market segments, distribution channels / value chains). The value of a company subsists in its ability to acquire, generate, distribute intangible resources, and strategically and operationally apply knowledge [21]. 
In this context, intellectual capital (IC) plays an important role in the development of bioeconomic projects. The size and speed of innovation depend on a functional knowledge base as well as on the importance attached to intellectual capital in organizations. The development of intellectual capital has the potential to contribute to developments in the field of bio-economy through the development of innovation capacities resulting from the intensification of investments associated with this form of capital. Innovative capacities will result in opportunities to create new products, services or work practices [22].

Our research aimed to emphasize the benefits of the dynamics of the intellectual capital growth on the evolution of bio-economy. Therefore we studied the established link between the Energy Intensity of the Economy (EIE) and a number of factors that can measure the intellectual capital, namely the stock market capitalization of the Bitcoin digital coin (MkCapBTC), Patent applications listed by European Patent Office (CB) and the Turnover from Innovation (CA). The data were taken from the Eurostat European Statistics Institute and from a very important trading platforms of cryptocurrency, coinbase.com. The study is based on data between 2015 and 2017.

General hypothesis: The evolution of bio-economics at European and Romanian level is influenced by intellectual capital;

H1: There exists a considerable link between the EIE and the MkCapBTC;

H2: Between the EIE and the CB there is a considerable link;

H3: There exists a considerable link between the EIE and the CA_INV.

The results of our analysis coincide with those of the authors Gârdan et al. [25], namely in a knowledge based economy the link between sustainable bioeconomy and companies is achieved by Intellectual Capital. The intangible assets of Intellectual Capital coming from the external environment of a company in the shape of Relational Capital have great value, as they can offer competitive advantages. At European level, between bioeconomy and the turnover from innovation as a percentage of the total turnover, there is a strong direct link, the value of the correlation coefficient is equal to 0.954 . The second variable that influences bioeconomics is the variable proposed by us namely Market Capitalization of Bitcoin. At Romanian level the bioeconomy is influenced most by the number of Patent applications to the European Patent Office in proportion of $81 \%$. Just as at the level of the European Union, and at the level of Romania, the indicator proposed by us influences the bioeconomy. We believe that the progress of bioeconomy cannot be achieved without the harness of intellectual capital.

\section{Literature Review}

From the research of the literature review in the field of bioeconomy and intellectual capital we identified a series of articles from the Web of Science database, the selection being made according to the following characteristics: they were published in 2010-2018; by keywords: sustainability, sustainable development, bioeconomy, intellectual capital, biotechnology, innovation, economic development, human capital and relational capital. Thus, 17 articles were extracted from the database, which we grouped by title, year, and authors (see Table 1):

Table 1. Selection of articles from database

\begin{tabular}{|ccc|}
\hline Title & Authors & Year \\
\hline A framework of actions for strong sustainability & Oliveira Neto, G.C.D., Pinto, L.F.R., Amorim, & 2018 \\
& M.P.C., Giannetti, B.F., Almeida, C.M.V.B.D. & \\
\hline $\begin{array}{c}\text { Knowledge-based bioeconomy: The use of intellectual } \\
\text { capital in food industry of Serbia }\end{array}$ & $\begin{array}{c}\text { Boljanovic, J.D., Dobrijević, G., Cerovic, } \\
\text { S., Alcakovic, S., Djokovic, F. }\end{array}$ \\
\hline $\begin{array}{c}\text { A demand-side perspective of bioeconomy: The influence } \\
\text { of online intellectual capital on consumption }\end{array}$ & $\begin{array}{c}\text { Vătămănescu, E.-M., Alexandru, V.A., Cristea, } \\
2018\end{array}$ \\
\hline
\end{tabular}




\begin{tabular}{|c|c|c|}
\hline $\begin{array}{l}\text { Bioeconomy development and using of intellectual capital } \\
\text { for the creation of competitive advantages by Smes in the } \\
\text { field of biotechnology }\end{array}$ & $\begin{array}{l}\text { Gârdan, D.A., Andronie, M., Gârdan, I.P., } \\
\text { (...), Iatagan, M., Hurloiu, I. }\end{array}$ & 2018 \\
\hline $\begin{array}{l}\text { The University role in developing the human capital for a } \\
\text { sustainable bioeconomy }\end{array}$ & $\begin{array}{c}\text { Bejinaru, R., Hapenciuc, C.V., Condratov, } \\
\text { I., Stanciu, P. }\end{array}$ & 2018 \\
\hline $\begin{array}{l}\text { Consumer Ewom communication: The missing link } \\
\text { between relational capital and sustainable bioeconomy in } \\
\text { health care services }\end{array}$ & $\begin{array}{c}\text { Gheorghe, I.R., Purcărea, V.L., Gheorghe, } \\
\text { C.M. }\end{array}$ & 2018 \\
\hline $\begin{array}{l}\text { Intensity of involvement of teachers and researchers } \\
\text { from Romanian Universities in bioeconomy knowledge } \\
\text { flows }\end{array}$ & Neştian, A.S., Tiţă, S., Guţă, A.L. & 2018 \\
\hline $\begin{array}{c}\text { Types of intellectual capital employed in bioeconomic } \\
\text { projects - A longitudinal case study }\end{array}$ & $\begin{array}{l}\text { Săndulescu, M.-S., Stoica, D.A., Albu, C.- } \\
\text { N., Albu, N. }\end{array}$ & 2018 \\
\hline $\begin{array}{l}\text { Intellectual capital and financial performance of biotech } \\
\text { companies in the pharmaceutical industry }\end{array}$ & $\begin{array}{l}\text { Anghel, I., Siminică, M., Cristea, M., Sichigea, } \\
\text { M., Noja, G.G. }\end{array}$ & 2018 \\
\hline $\begin{array}{l}\text { The role of universities in consolidating intellectual } \\
\text { capital and generating new knowledge for a sustainable } \\
\text { bio-economy }\end{array}$ & Tiron-Tudor, A., Nistor, C.S., Ştefănescu, C.A. & 2015 \\
\hline $\begin{array}{l}\text { The role of public subsidies for efficiency and } \\
\text { environmental adaptation of farming: A multi-layered } \\
\text { business model based on functional foods and rural } \\
\text { women }\end{array}$ & $\begin{array}{l}\text { Varela-Candamio, L., Calvo, N., Novo-Corti, } \\
\text { I. }\end{array}$ & 2015 \\
\hline $\begin{array}{l}\text { Seeds of accumulation: Molecular breeding and the seed } \\
\text { corn industry in Hawai' }{ }^{\prime} i\end{array}$ & Schrager, B., Suryanata, K. & 2015 \\
\hline $\begin{array}{l}\text { Challenging the bioeconomy: The dynamics of collective } \\
\text { action in Argentina }\end{array}$ & Arancibia, F. & 2013 \\
\hline $\begin{array}{l}\text { Theorizing the Bioeconomy: Biovalue, Biocapital, } \\
\text { Bioeconomics or ... What? }\end{array}$ & Birch, K., Tyfield, D. & 2013 \\
\hline $\begin{array}{c}\text { High technology in emerging markets Building } \\
\text { biotechnology clusters, capabilities and competitiveness } \\
\text { in India }\end{array}$ & Ahn, M.J., Hajela, A., Akbar, M. & 2012 \\
\hline $\begin{array}{l}\text { Towards a high-performance bioeconomy determining } \\
\text { cluster priorities and capabilities in New Zealand }\end{array}$ & $\begin{array}{l}\text { Ahn, M.J., Meeks, M., Bednarek, R., Ross, } \\
\text { C., Dalziel, S. }\end{array}$ & 2010 \\
\hline $\begin{array}{l}\text { Patenting human pluripotent cells: Balancing } \\
\text { commercial, academic and ethical interests }\end{array}$ & Bahadur, G., Morrison, M. & 2010 \\
\hline
\end{tabular}

The objective of the exploratory study of the Boljanovic et al. was to identify and analyze the indicators of intellectual capital in food industry of Serbia [23]. The paper investigated managers' perceptions of their usefulness, practical application, and factors that influence them. The respondents were surveyed by questionnaire. They were top managers from 18 food organizations, committed to the bioeconomy concept. The survey items were divided into three subcategories: human, structural, and relational capital. The results show that all indicators were perceived as very important, relational capital indicators being the most useful of all. The study provides a perspective on managing intellectual capital in bioeconomy. 
The paper of Vătămănescu et al. aims to address a demand side perspective of bioeconomy by laying emphasis on the digitalization of markets and, subsequently, on the consumption patterns at the macroeconomic scale [24]. The study investigates the influences of intellectual capital on the consumption patterns through the lens of bioeconomy. The focus is set on the bio products consumption in two European countries relying on a sample of over 700 active online consumers. Processed through a structural equation modeling technique, the data indicated the existence of significant influences among the considered variables.

There are attempts to present the perceptions and opinions of the managers of small and medium enterprises in applied biotechnology on the importance of intellectual capital and the application of knowledge management principles to create and maintain competitive advantages [25]. Enterprises that develop a sustainable knowledge management system that they integrate into their marketing strategy have the most prominent position on the market and gain multiple competitive advantages. The research highlights that the strategic decision regarding the implementation of a knowledge management system and the intelligent use of intellectual capital resources are correlated with variables such as: the managers' level of education in the field, thus correlating managers' activity to organizational culture. Knowledge, for new business models, is a good asset that can be capitalized; from this perspective, the implications at the level of marketing strategies are in the same time diverse and complex.

The developments in the bioeconomy domain should reflect their usefulness regarding the provision of sustainable solutions for future competitiveness growth by using natural resources. Latterly the relevance of education, training and research in bioeconomy domain is obvious because these types of solutions which may be generated mainly by educated individuals who contribute to the better specialization of the human capital on this market. The aim of the research is to analyze the influence of universities upon the human capital activating in the bioeconomy sectors throughout the transfer of three types of knowledge: rational, emotional and spiritual. The data obtained capture the facets of human capital in interdependence and interrelation with the dimensions of bioeconomy. The study can be a starting point to designing strategies for increasing the human capital of organizations in various fields as well as of systems in the bioeconomy field.

The world today faces many challenges that may be solved by using the principles of bioeconomy. Bioeconomy had a multi-disciplinary approach with the objective of an integrated scope, namely, to achieve sustainable development. In a knowledge based economy, the link between sustainable bioeconomy and companies is achieved by Intellectual Capital. The intangible assets of Intellectual Capital coming from the external environment of a company in the shape of Relational Capital have great value, as they can offer competitive advantages.

The interdependency between the intellectual capital and the financial performance of biotechnological (biotech) companies was performed for 24 biotech companies during 2002-2014, based on several indicators available on the Thomson Reuters database. The financial performance was measured through the return on assets (ROA), return on equity (ROE) and the debt-to-equity ratio (DE). In order to capture the intellectual capital, the focus was on designing a new indicator, proposed by the authors, respectively the efficiency of research and development expenditures (ECD), along with another proxy, previously attested by the literature and reflected through the market to-book ratio (MTB). The research methodology belonged on applying the correlation method, regression, and structural equations modelling (SEM). The results revealed a significant negative relationship between ROA, ROE and MTB, which contradicts the literature and suggests that, for this particular type of companies, MTB was not relevant to express the intellectual capital. MTB was positively correlated with the DE indicator. When they used the ECD, the results attested a strongly positive and significant relation with ROA and ROE, and a negative one with DE. Therefore, the applied tests confirm ECD as the most suitable indicator to appreciate the intellectual capital for the biotech companies in the pharmaceutical industry [26].

At the base of the transformations taking place in the economy, knowledge will be found under different circumstances - raw material, production factor or finished product. Thus, economic processes will in fact transform and adapt to change and new demands through knowledge [27]. 
Companies that develop a sustainable knowledge management system that they integrate into their marketing strategy have the most prominent position on the market and gain multiple competitive advantages.

The conclusion to be drawn from the revision of the literature is that knowledge management and intellectual capital are indissolubly linked to the application of the principles of the knowledgebased economy, which are also the basis for the current evolution of bioeconomy.

\section{Materials and Methods}

In the last decade, a significant number of governmental organizations international, regional and national authorities have developed strategies for bioeconomy. The OECD and the European Commission have developed key strategic documents [28] and several European countries (Austria, Denmark, France and the Netherlands) have developed national policy strategies for bioeconomy. The European Commission through its statistical database defines intellectual capital through the following indicators that can influence the bio-economy: R\&D personnel by sector - \% of active population, Patent applications to the European Patent Office, Turnover from innovation as a percentage of Total, Graduates by education level and Labor status by educational attained level. From these indicators, we chose the indicators: Patent applications listed by European Patent Office (CB) and Turnover from innovation as a percentage of Total Turnover (CA_INV) to analyze because they contain in database, data during the analyzed period 2015 - 2017, for both the European Union and Romania. Also intellectual capital can be evaluated by various methods, but the easiest method is represented by the difference between the market established value of one company and the total value of its assets. Although intellectual capital can now be considered somewhat abstract, in the economy, the concept of intellectual capital is defined as "an estimate of a person's ability to produce income through work" [11]. Intellectual capital is considered a hidden treasure to help companies, the economy and, implicitly, bio-economy to develop in this age of technology and knowledge. That is why we have proposed our indicator of measuring the intellectual capital (human capital), the Bitcoin's Market Capitalization (MkCapBTC). In the analysis we will see if the indicators identified in the literature influence the development of the bioeconomy more than the indicator proposed by us. The tools and methods of analysis used in the study are: the collection of the value of each indicator by the method of observation, sorting and grouping of data according to the criteria of the European Union and Romania; creating graphs using the Excel spreadsheet program in the Microsoft Office 2010 package for identified indicator values and then sorting them for 3 years; statistical analysis using ANOVA, SPSS 19.0, and Pearson correlation indices. In the regression analysis we used those indicators mentioned above as independent variables and as the dependent variable we used the variable Energy Intensity of the Economy. As the analysis tracks the inflow of intellectual capital on the bioeconomy, the indicators defining the bioeconomy will be dependent variable. ANOVA may use a single variable as a dependency. That is why we extracted from the European Commission database only the values of the indicator Energy Intensity of the Economy because it contains values at the level of Romania and at the level of the European Union for all 3 analyzed years.

The countries under analysis are presented in Table 2.

Table 2. Energy consumption by 36 countries [27]

\begin{tabular}{|l|c|c|c|}
\hline \multicolumn{1}{c|}{ GeolTime } & $\mathbf{2 0 1 5}$ & $\mathbf{2 0 1 6}$ & $\mathbf{2 0 1 7}$ \\
\hline Belgium & $\mathbf{3 4 , 2}$ & $\mathbf{3 5 , 9}$ & $\mathbf{3 6 , 3}$ \\
\hline Bulgaria & 9 & 9,5 & 9,7 \\
\hline Czech Republic & 23,6 & 24,2 & 24,8 \\
\hline Denmark & 13,6 & 14 & 14,4 \\
\hline
\end{tabular}




\begin{tabular}{|c|c|c|c|}
\hline Germany & 208,9 & 212,1 & 216,4 \\
\hline Estonia & 2,8 & 2,8 & 2,8 \\
\hline Ireland & 10,8 & 11,2 & 11,6 \\
\hline Greece & 15,5 & 16,5 & 16,7 \\
\hline Spain & 79,2 & 80,5 & 82,5 \\
\hline France & 141,3 & 145,3 & 147,2 \\
\hline Croatia & 6,2 & 6,6 & 6,6 \\
\hline Italy & 113,3 & 116,2 & 115,9 \\
\hline Cyprus & 1,6 & 1,7 & 1,8 \\
\hline Latvia & 3,9 & 3,8 & 3,8 \\
\hline Lithuania & 4,9 & 4,9 & 5,1 \\
\hline Luxembourg & 4 & 4 & 4 \\
\hline Hungary & 16,2 & 17,4 & 17,9 \\
\hline Malta & 0,5 & 0,6 & 0,6 \\
\hline Netherlands & 47,3 & 48,5 & 49,5 \\
\hline Austria & 26,7 & 27,5 & 28,1 \\
\hline Poland & 61,6 & 62,3 & 66,7 \\
\hline Portugal & 15,8 & 16 & 16,1 \\
\hline Romania & 21,7 & 21,9 & 22,3 \\
\hline Slovenia & 4,6 & 4,7 & 4,9 \\
\hline Slovakia & 10 & 10,1 & 10,4 \\
\hline Finland & 24,5 & 24,2 & 25,2 \\
\hline Sweden & 31,2 & 31,7 & 32,6 \\
\hline United Kingdom & 130 & 132,3 & 133,7 \\
\hline Iceland & 2,9 & 3,1 & 3,3 \\
\hline Norway & 18,5 & 18,8 & 18,9 \\
\hline Montenegro & 0,6 & 0,7 & 0,7 \\
\hline Former Yugoslav Republic of Macedonia & 1,8 & 1,9 & 1,9 \\
\hline Albania & 2,1 & 2 & 1,9 \\
\hline Serbia & 7,8 & 8,2 & 8,7 \\
\hline Turkey & 85,9 & 92,7 & 96,9 \\
\hline Bosnia and Herzegovina & 3,4 & 3,6 & 3,8 \\
\hline Mean & 32,94 & 33,82 & 34,55 \\
\hline
\end{tabular}

The Energy consumption measures the total energy demand of a country excluding all nonenergy use of energy carriers (e.g. natural gas used not for combustion but for producing chemicals). Figure 1 shows that $80 \%$ of the analyzed countries are below average. Countries that are above the average energy demand were excluded from the analysis. 


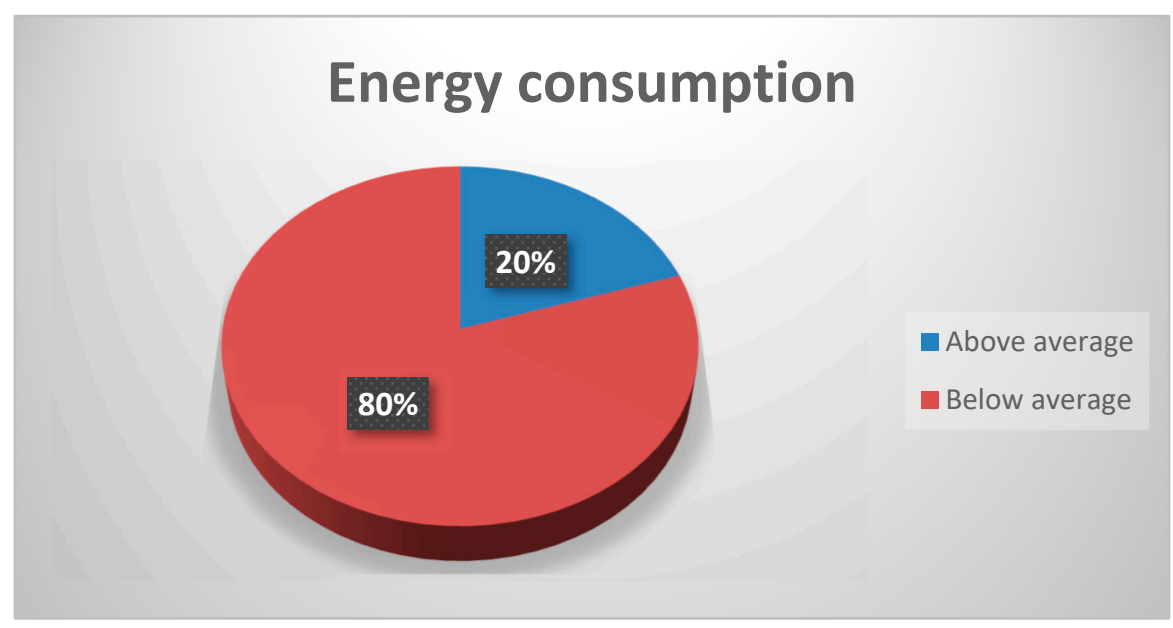

Figure 1. Energy consumption by 36 countries

\subsection{Setting goals and assumptions}

Considering intellectual capital as a key resource for the expansion of organizational intelligence, economic growth and especially for the development of bio-economics, we have used the following objectives (of our methodology) for analysis:

- O1: Determining the link and the percentage in which Bitcoin's Market Capitalization (MkCapBTC) influences the EIE, at European level and at the level of Romania;

- O2: Determining the link and the percentage in which the Patent applications listed by European Patent Office (CB) influences the EIE at European level and, in particular, at the level of Romania;

- O3: Determining the link and the percentage in which the Turnover from innovation as a percentage of Total Turnover (CA_INV) influences the EIE at European and national level.

Further, considering our scientific approach, we have established the following assumptions:

General hypothesis: The evolution of bio-economics at European and Romanian level is influenced by intellectual capital;

- H1: There exists a considerable link between the EIE and the MkCapBTC;

- H2: Between the EIE and the CB there is a considerable link;

- H3: There exists a considerable link between the EIE and the CA_INV.

\subsection{Operationalization of variables and data collection}

The study is based on data between 2015 and 2017 on the EIE, the stock market capitalization of the Bitcoin digital coin, Patent applications listed by European Patent Office and the Turnover from Innovation. The data were taken from the Eurostat European Statistics Institute and from a very important trading platforms of cryptocurrency, coinbase.com.

The variables, described by their nature and also, used in the model, are summarized in Table 3. On these data the method of observation and statistical analysis were applied to confirm or to invalidate the assumptions of the research. 
Table 3. The variables used in the econometric model

\begin{tabular}{|c|c|c|c|}
\hline No. & Variables & Economic expression & Statistical expression \\
\hline 1 & EIE & $\begin{array}{l}\text { Energy Intensity of the Economy [28] } \\
\text { In the current energy context, sustainable } \\
\text { development means ensuring energy } \\
\text { needs, but not by increasing its use (except } \\
\text { for renewable energy), but by increasing } \\
\text { energy efficiency, modernizing } \\
\text { technologies and restructuring the } \\
\text { economy. } \\
\text { EIE = CBIE / GDP } \\
\text { CBIE = Total Gross Energy Usage } \\
\text { GDP = gross domestic product }\end{array}$ & $\begin{array}{l}\text { Dependent Variable } \\
\text { Resolvable variable } \\
\text { Quantitative dimension } \\
\text { Purpose of selecting the } \\
\text { variable: defining bio-economy }\end{array}$ \\
\hline 2 & MkCapBTC & $\begin{array}{l}\text { Market Capitalization of Bitcoin [29] } \\
\text { Bitcoin is a virtual currency that allows } \\
\text { anonymous ownership and transfer } \\
\text { without recourse to financial institutions. } \\
\text { MkCapBTC = the number of digital coins } \\
\text { * the market value of a currency }\end{array}$ & $\begin{array}{l}\text { Independent variable } \\
\text { Variable predictor } \\
\text { Quantitative dimension } \\
\text { Purpose of selecting the } \\
\text { variable: defining intellectual } \\
\text { capital }\end{array}$ \\
\hline 3 & $\mathrm{CB}$ & $\begin{array}{l}\text { Patent applications listed by European } \\
\text { Patent Office [30] } \\
\text { The indicator measures claims for the } \\
\text { protection of an invention directed in a } \\
\text { direct manner at the European Patent } \\
\text { Office (EPO) or submitted under the } \\
\text { Patent Cooperation Treaty and } \\
\text { designating an EPO (Euro-PCT), whether } \\
\text { accepted or not. The data cover the total } \\
\text { number of applications listed per } \\
\text { country. If an application includes more } \\
\text { than one inventor, the submission is } \\
\text { equally divided between all and then in } \\
\text { their home countries, thus avoiding } \\
\text { double counting. }\end{array}$ & $\begin{array}{l}\text { Independent variable } \\
\text { Variable predictor } \\
\text { Quantitative dimension } \\
\text { Purpose of selecting the } \\
\text { variable: defining intellectual } \\
\text { capital }\end{array}$ \\
\hline 4 & CA_INV & $\begin{array}{l}\text { Turnover from Innovation as a } \\
\text { proportion of the total Turnover [31] } \\
\text { This parameter is defined as the ratio } \\
\text { between the turnover of the new } \\
\text { products for the company and the new } \\
\text { ones on the market as a proportion of the } \\
\text { total turnover. It is based on the } \\
\text { Community Innovation Survey and } \\
\text { covers at least all enterprises with } 10 \text { or }\end{array}$ & $\begin{array}{l}\text { Independent variable } \\
\text { Variable predictor } \\
\text { Quantitative dimension } \\
\text { Purpose of selecting the } \\
\text { variable: defining intellectual } \\
\text { capital }\end{array}$ \\
\hline
\end{tabular}




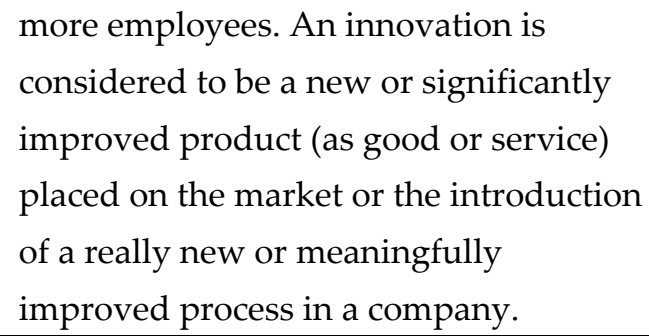

The systematization and grouping of data, indices, statistical analysis were used as methods in conducting scientific research.

Regression shows how a variable is dependent on another variable. The equation of the regression model is expressed as follows (1):

$$
\mathrm{EIE}=\beta_{0}+\beta_{1}{ }^{*} \mathrm{MkCapBTC}+\beta_{2}{ }^{*} \mathrm{CB}+\beta_{3}{ }^{*} \mathrm{CA} \_\mathrm{INV}+\varepsilon
$$

\subsection{Analyzing data, obtaining and interpreting the results}

This analysis explores the link between the Energy Intensity of the Economy and a number of factors that can define the intellectual capital such as: Market Capitalization of Bitcoin, the number of Patent applications listed by European Patent Office and the Turnover from innovation, with the ultimate goal of generating a statistical regression model to analyze which factor had the greatest influence on the development of the bio-economy.

The analysis was carried out at European (EIE-E) and Romanian level (EIE-R).

\section{Results}

Among other things, the European Union and the Organization for Economic Co-operation and Development (OECD) have highlighted the need for global cooperation to facilitate the growth of bio-economic activities.

In Figure 2 we can see the magnitude to which measures have been taken to create a global economy.

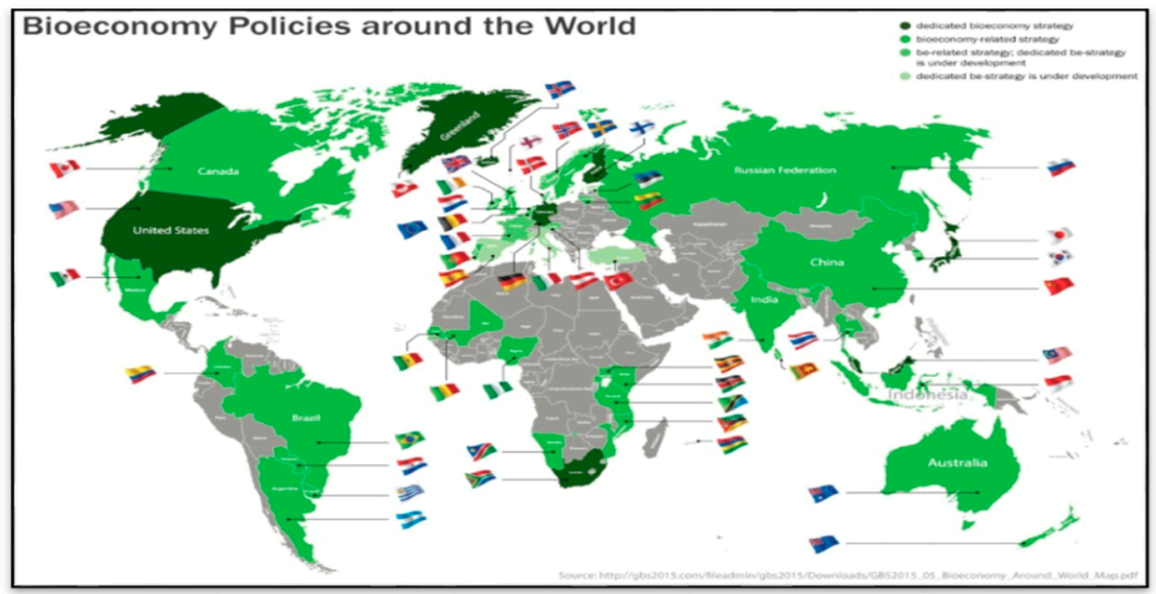

Figure 2. Bioeconomic measures worldwide [32]

The number of publications listed in Scopus referring to bio-economy is presented in Figure 3. 


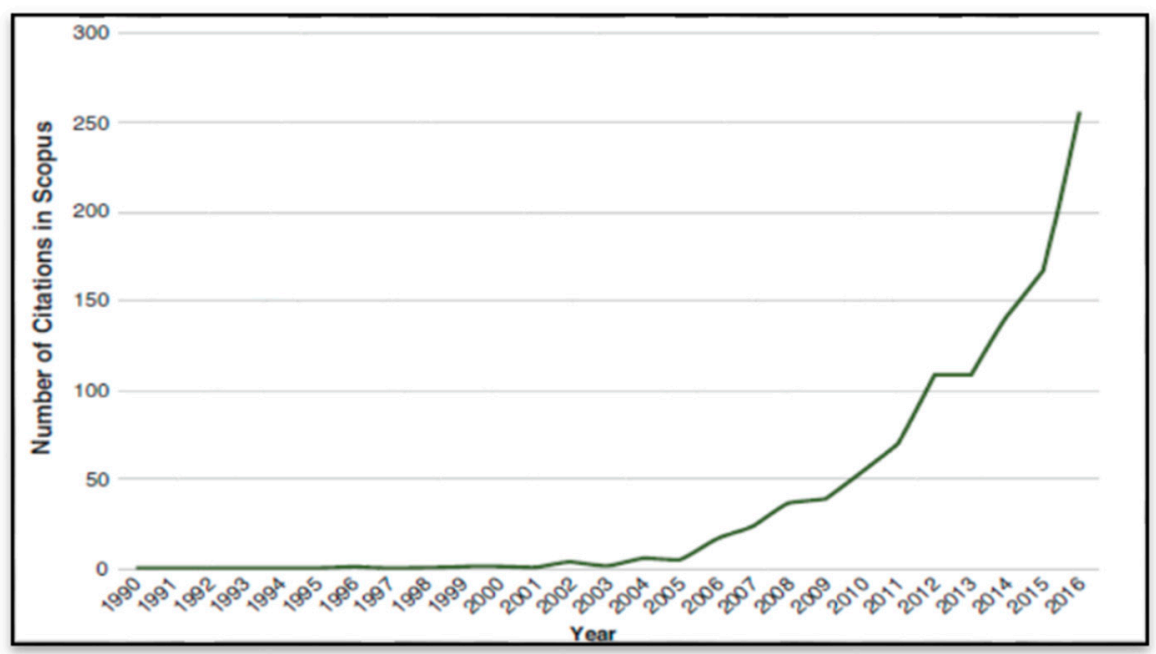

Figure 3. The number of citations listed in Scopus referring to bio-economy [33]

Considering the crisis caused by the current economy, we can state, according to market statistics, that the market value of many large companies is mostly given by intellectual capital rather than by the total value of the assets measured at market value.

\subsection{Empirical analysis at European level}

It is found that the most significant link is between the Energy Intensity of the Economy and the Turnover from innovation (Table 4). Between the dependent variable - the Energy Intensity of the Economy - and the independent variable - the Turnover from innovation as a percentage of the total turnover - there is really a strong direct link, the value of the correlation coefficient is equal to +0.954 , with a Sig. value less than 0.05 .

Table 4. The link that exists between variables at European level (own processing data using the SPSS 19 statistical program)

\begin{tabular}{|l|l|c|c|c|c|}
\hline \multicolumn{5}{c}{ Correlations } \\
\hline \multirow{2}{*}{ Pearson Correlation } & EIE-E & 1.000 & -.726 & .531 & .954 \\
& MkCapBTC & -.726 & 1.000 & -.724 & -.997 \\
& CB & .531 & -.724 & 1.000 & .779 \\
\hline & CA_INV & .954 & -.997 & .779 & 1.000 \\
\hline \multirow{5}{*}{ Sig. (1-tailed) } & EIE-E & - & .012 & .011 & .009 \\
\hline & MkCapBTC & .012 & - & .024 & .027 \\
\hline & CB & .011 & .024 & - & .021 \\
\hline N & CA_INV & .047 & .027 & .0216 & - \\
\hline & EIE-E & 3 & 3 & 3 & 3 \\
\hline & MkCapBTC & 3 & 3 & 3 & 3 \\
\hline & CB & 3 & 3 & 3 & 3 \\
\hline & CA_INV & 3 & 3 & 3 & 3 \\
\hline
\end{tabular}


Table 5 highlights the fact that $95 \%$ of the variation of the Energy Intensity of the Economy can be explained by the influence of independent variables. The difference is due to other conjunctural factors.

Table 5. The percentage of the link between European variables (own processing data using the SPSS 19 statistical program)

\begin{tabular}{|c|c|c|c|c|}
\hline \multirow{2}{*}{ Model } & R & \multicolumn{4}{|c|}{ Model Summary } \\
& R Square & $\begin{array}{c}\text { Adjusted R } \\
\text { Square }\end{array}$ & Std. Error of the Estimate \\
\hline 1 & $.958^{\mathrm{b}}$ & .918 & .505 & 2901.64993 \\
\hline $\mathbf{2}$ & $.895^{\mathrm{c}}$ & .801 & .701 & 2234.68446 \\
\hline 3 & $.849^{\mathrm{d}}$ & .720 & .665 & 1884.86021 \\
\hline
\end{tabular}

a. dependent variable: EIE-E; b. independent variables: MkCapBTC, CB, CA_INV; c. independent variables: $\mathrm{CB}, \mathrm{CA}$ _INV; d. independent variables: CA_INV.

Table 5 shows for each regression model the value of the correlation coefficient $(\mathrm{R})$, the value of the coefficient of determination (R Square) and the standard error. The correlation coefficient (R) increases as many variables are introduced into the model. Model 1 analyzes the correlation between all the variables included in the study. Model 2 and 3 eliminate the variables in order of the weakest influence: MkCapBTC and CB, respectively (see Pearson coefficient in Table 4).

The equation (1) of the regression model according to the data presented below is the following (2):

$$
\mathrm{EIE}-\mathrm{E}=(-3641.119)+22.354^{*} \mathrm{MkCapBTC}+13.066^{*} \mathrm{CB}+62.455^{*} \mathrm{CA} \_\mathrm{INV}
$$

The Regression coefficients are as stated in Table 6, e.g. $\beta_{0}=-3641.119 ; \beta_{1}=+22.354 ; \beta_{2}=+13.066$; $\beta_{3}=+62.455$.

Table 6. The Regression coefficients at European level (own processing data using the SPSS 19

\begin{tabular}{|l|c|c|c|c|c|c|c|}
\hline \multicolumn{7}{|c|}{$\begin{array}{c}\text { Statistical program) } \\
\text { Coefficients }\end{array}$} \\
\hline & $\begin{array}{c}\text { Unstandardized } \\
\text { Coefficients }\end{array}$ & $\begin{array}{c}\text { Standardized } \\
\text { Coefficients }\end{array}$ & $\mathbf{t}$ & Sig & \multicolumn{2}{c|}{$\begin{array}{c}\text { Collinearity } \\
\text { Statistics }\end{array}$} \\
\hline & $\boldsymbol{\beta}$ & Std. Error & $\boldsymbol{\beta}$ & & & Tolerance & VIF \\
\hline (Constant) & -3641.119 & 23414.050 & 0.000 & 0.000 & 0.000 & 0.000 & 0.000 \\
\hline CB & 13.066 & 0.001 & 0.476 & 0.157 & 0.0901 & 0.393 & -2.543 \\
\hline CA_INV & 62.455 & 1234.000 & 0.583 & 0.402 & 0.0970 & 0.293 & 2.743 \\
\hline MkCapBTC & 22.354 & 356.235 & 0.367 & 0.207 & 0.0720 & 0.172 & 1.892 \\
\hline \multicolumn{2}{r|}{ a. dependent variable: EIE-E; independent variables: CB, CA_INV, MkCapBTC. } \\
\hline
\end{tabular}

Model 1 reflects the influence of the evolution of the number of Patent applications to the European Patent Office, the Turnover from innovation and the stock market capitalization of the Bitcoin digital coin, all on the Energy Intensity of the Economy at European level. 
From the analyzed model, a few ideas are drawn:

- $\quad$ if we keep constant the Turnover from innovation and the value of Market capitalization of the Bitcoin, a percentage increase in the number of Patent applications listed by European Patent Office generate an increase in the Energy Intensity of the Economy by 13 percent;

- $\quad$ if we maintain constant the number of Patent applications listed by European Patent Office and the value of Bitcoin's stock market capitalization, a percentage increase in Turnover from innovation leads to an increase in the Energy Intensity of the Economy by 62 percent;

- if we maintain constant the value of Turnover from innovation and the number of Patent applications listed by European Patent Office, a percentage increase in the value of Bitcoin's stock market capitalization leads to an increase in the Energy Intensity of the Economy by 22 percent.

Compliance with the hypothesis required by the regression analysis can be graphically checked using the histogram in Figure 4.

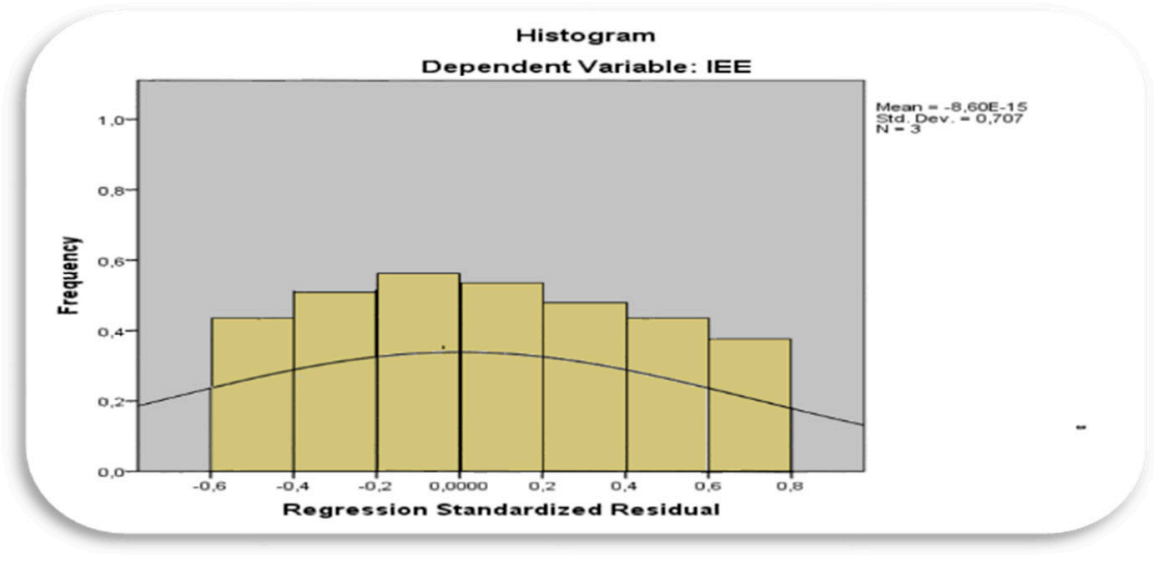

Figure 4. Verifying the normality of the research at European level through the histogram (own processing data using the SPSS 19 statistical program)

\subsection{Empirical analysis at the Romanian level}

It is noted that the most significant link is between the Energy Intensity of the Economy and the number of Patent applications to the European Patent Office (Table 7). Between the dependent variable - the Energy Intensity of the Economy - and the independent variable - the number of Patent applications to the European Patent Office - there is really a strong direct link, the value of the correlation coefficient is +0.810 , with a Sig. value less than 0.05 .

Table 7. The link that exists between variables at the Romanian level (own processing data using the SPSS 19 statistical program)

\begin{tabular}{|l|l|r|r|r|r|}
\hline \multicolumn{7}{|c|}{ Correlations } \\
\hline \multirow{2}{*}{ Pearson Correlation } & EIE-R & EIE-R & MkCapBTC & CB & CA_INV \\
\cline { 2 - 8 } & MkCapBTC & 1.000 & -.526 & .810 & .732 \\
\cline { 2 - 8 } & CB & -.526 & 1.000 & -.632 & -.997 \\
\cline { 2 - 7 } & CB & .810 & -.732 & 1.000 & .779 \\
\hline
\end{tabular}




\begin{tabular}{|l|l|r|r|r|r|r|}
\hline \multirow{2}{*}{ Sig. (1-tailed) } & CA_INV & .732 & -.897 & .779 & 1.000 \\
\hline & EIE-R & - & & .011 & .021 & .008 \\
\hline MkCapBTC & .011 & - & & .024 & .027 \\
\hline CB & .024 & .024 & - & .021 \\
\hline CA_INV & .027 & .027 & .0216 & - \\
\hline $\mathbf{N}$ & EIE-R & 3 & 3 & 3 & 3 \\
\hline MkCapBTC & 3 & 3 & 3 & 3 \\
\hline CB & 3 & 3 & 3 & 3 \\
\hline
\end{tabular}

Table 8 highlights the fact that $92 \%$ of the variation of Energy Intensity of the Economy can be explained by the influence of independent variables. The difference is due to other conjunctural factors.

Table 8. The percentage of the link between the variables at Romanian level (own processing data using the SPSS 19 statistical program)

\begin{tabular}{|c|c|c|c|c|}
\hline \multirow{2}{*}{ Model } & R & R Square & $\begin{array}{c}\text { Mdjusted R } \\
\text { Square }\end{array}$ & Std. Error of the Estimate \\
\hline 1 & $.926^{\mathrm{b}}$ & .915 & .605 & 3901.4513 \\
\hline 2 & $.797^{\mathrm{c}}$ & .903 & .701 & 4134.5846 \\
\hline 3 & $.738^{\mathrm{d}}$ & .821 & .665 & 1227.6021 \\
\hline
\end{tabular}

a. dependent variable: EIE-R; b. independent variables: MkCapBTC, CB, CA_INV; c. independent variables: CB, CA_INV; d. independent variables: CB.

Table 8 shows for each regression model the value of the correlation coefficient (R), the value of the coefficient of determination ( $R$ Square) and the standard error. The correlation coefficient (R) increases as many variables are introduced into the model. Model 1 analyzes the correlation between all the variables included in the study. Model 2 and 3 eliminate the variables in order of the weakest influence: MkCapBTC and CA_INV, respectively (see Pearson coefficient in Table 7).

The equation (1) of the regression model according to the data presented below is the following (3):

$$
\mathrm{EIE}-\mathrm{R}=841.328+12.305^{*} \mathrm{MkCapBTC}+43.136^{*} \mathrm{CB}+32.034 * \mathrm{CA} \_\mathrm{INV}
$$

The Regression coefficients are as stated in Table 9, e.g. $\beta_{0}=+841.328 ; \beta 1=+12.305 ; \beta 2=+43.136$; $\beta 3=+32.034$

Table 9. The Regression coefficients at Romanian level (own processing data using the SPSS 19 statistical program)

\begin{tabular}{|r|c|c|c|c|c|c|c|}
\hline Model 1 & \multicolumn{2}{|c|}{$\begin{array}{c}\text { Coefficients } \\
\text { Unstandardized } \\
\text { Coefficients }\end{array}$} & $\begin{array}{c}\text { Standardized } \\
\text { Coefficients }\end{array}$ & $\mathbf{t}$ & Sig & \multicolumn{2}{c|}{$\begin{array}{c}\text { Collinearity } \\
\text { Statistics }\end{array}$} \\
\hline & $\boldsymbol{\beta}$ & Std. Error & $\boldsymbol{\beta}$ & & & Tolerance & VIF \\
\hline (Constant) & 841.328 & 414.03 & 0.000 & 0.000 & 0.000 & 0.000 & 0.000 \\
\hline
\end{tabular}




\begin{tabular}{|l|c|c|c|c|c|c|c|}
\hline CB & 43.136 & 0.001 & 0.46 & 0.21 & 0.089 & 0.377 & 1.343 \\
\hline CA_INV & 32.034 & 231.00 & 0.67 & 0.29 & 0.090 & 0.298 & 1.533 \\
\hline MkCapBTC & 12.305 & 446.24 & 0.27 & 0.21 & 0.073 & 0.178 & 0.874 \\
\hline \multicolumn{2}{r|}{ a. dependent variable: EIE-R; independent variables: CB, CA_INV, MkCapBTC. } \\
\hline
\end{tabular}

The model reflects the influence of the evolution of the number of Patent applications to the European Patent Office, the Turnover from innovation and the stock market capitalization of the Bitcoin digital coin on the Energy Intensity of the Economy at the level of Romania.

Thus, from the analyzed model a few ideas are drawn:

- if we keep constant the Turnover from innovation and the value of Market capitalization of the Bitcoin, a percentage increase in the number of Patent applications listed by European Patent Office leads to an increase in the Energy Intensity of the Economy by 43 percent;

- if we maintain constant the number of Patent applications listed by European Patent Office and the value of Bitcoin's stock market capitalization, a percentage increase in Turnover from innovation leads to an increase in the Energy Intensity of the Economy by 32 percent;

- if we maintain constant the value of turnover from innovation and the number of Patent applications listed by European Patent Office, a percentage increase in the value of Bitcoin's stock market capitalization leads to an increase in the Energy Intensity of the Economy by 12 percent.

Compliance with the hypothesis required by the regression analysis can be graphically checked using the histogram in Figure 5.

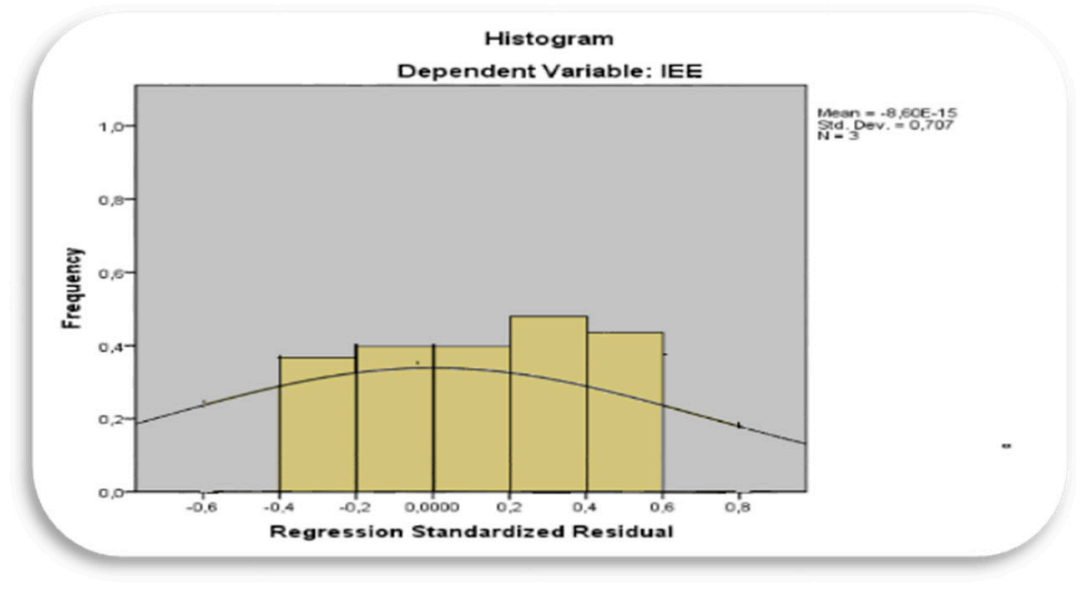

Figure 5. Verifying the normality of the research at Romanian level through the histogram (own processing data using the SPSS 19 statistical program)

\subsection{Hypothesis testing using data processed}

In this part of the analysis we will perform the test of the force of each hypothesis, testing being done predominantly with the help of figures and graphs from the previous parts of the study.

Thus, Table 10 systemizes:

- Pearson correlation coefficients to determine whether there is a significant link between the dependent variable aka Energy Intensity of the Economy and the independent variables that 
characterize intellectual capital: Market Capitalization of Bitcoin, Patent applications listed by European Patent Office and the Turnover from innovation as a percentage of the total Turnover;

- Regression coefficients that determine the degree of influence of independent variables on the bio-economy.

Table 10. Systematization of regression coefficients and Pearson coefficients (own processing data using the SPSS 19 statistical program)

\begin{tabular}{|c|c|c|c|c|}
\hline \multirow{2}{*}{$\begin{array}{l}\text { Intellectual } \\
\text { capital }\end{array}$} & \multicolumn{2}{|c|}{ Pearson coefficients } & \multicolumn{2}{|c|}{ Regression coefficients } \\
\hline & $\begin{array}{c}\text { European } \\
\text { Level }\end{array}$ & $\begin{array}{c}\text { Romanian } \\
\text { Level }\end{array}$ & $\begin{array}{c}\text { European } \\
\text { Level }\end{array}$ & $\begin{array}{c}\text { Romanian } \\
\text { Level }\end{array}$ \\
\hline MkСарВTC & -.726 & -.526 & 13.066 & 12.305 \\
\hline CB & .531 & .810 & 22.354 & 43.136 \\
\hline CA_INV & .954 & .732 & 62.455 & 32.034 \\
\hline
\end{tabular}

On the other hand, Table 11 summarizes the assumptions made at the beginning of the research and the decisions regarding their validation or invalidation based on the econometric model used.

Table 11. Validation of hypotheses

\begin{tabular}{|c|c|c|c|}
\hline \multirow[t]{2}{*}{ Aim } & \multirow[t]{2}{*}{ Hypotheses } & \multicolumn{2}{|c|}{$\begin{array}{l}\text { Decision using the regression } \\
\text { model }\end{array}$} \\
\hline & & $\begin{array}{c}\text { European } \\
\text { Level }\end{array}$ & $\begin{array}{c}\text { Romanian } \\
\text { Level }\end{array}$ \\
\hline $\begin{array}{l}\text { Highlighting the } \\
\text { benefit of } \\
\text { developing }\end{array}$ & $\begin{array}{l}\text { H1: There is a significant link between } \\
\text { the Energy Intensity of the Economy } \\
\text { and the Bitcoin Market Capitalization }\end{array}$ & $\begin{array}{l}\text { The hypothesis is } \\
\text { validated }\end{array}$ & $\begin{array}{l}\text { The hypothesis } \\
\text { is validated }\end{array}$ \\
\hline $\begin{array}{l}\text { intellectual } \\
\text { capital in the } \\
\text { development of } \\
\text { bio-economy }\end{array}$ & $\begin{array}{l}\text { H2: Between the Energy Intensity of the } \\
\text { Economy and the Patent applications } \\
\text { listed by European Patent Office there } \\
\text { is a significant link }\end{array}$ & $\begin{array}{l}\text { The hypothesis is } \\
\text { validated }\end{array}$ & $\begin{array}{l}\text { The hypothesis } \\
\text { is validated }\end{array}$ \\
\hline & $\begin{array}{l}\text { H3: There is a significant link between } \\
\text { the Energy Intensity of the Economy } \\
\text { and the Turnover from innovation. }\end{array}$ & $\begin{array}{l}\text { The hypothesis is } \\
\text { validated }\end{array}$ & $\begin{array}{l}\text { The hypothesis } \\
\text { is validated }\end{array}$ \\
\hline
\end{tabular}

\section{Discussion}

Edvinsson and Malone described the intellectual capital as a metaphor. They imagined the firm as a tree. They overlapped the compiled plans of the company, the reports annually and quarterly developed, the brochures and all other documents of the firm as the trunk, as well as the branches and the leaves of the living organism. The wise angle will be the examination from the point of view of fruit production. The biases might evolve from the judging of only the visible side of the tree. Since an important part of the tree is out of sight. Even if we appreciate the tree as being healthy starting 
from the fruits (tasty and with nice color), it will be of real interest to study the tree's roots in the view of its evolution in the future. Thus might be described the intellectual capital [34].

From 1947 till 2011 there was an important shift in the balance of productive and unproductive economy of US. The starting point of such an analysis was the Marxist theory that the knowledge and information as economic categories are unproductive. The first observed pattern phase, meaning the 1947-79 one, had as absolute priority the productive accumulation. Beginning with the 1980s, there was a fast and important shift toward the unproductive activities (accumulation), taking various developing forms as income, fixed assets and employment. The shining production of explosive knowledge and information became an important proportion of capital stock as well as of unproductive income. The rapid changing of the balance between the stagnant productive accumulation and fast rising of unproductive one gave birth to an enhanced exploitation of productive workers and to a widened inequality of income [35].

One of the most important aspect of modern bio-economy is represented by the digitalization of markets, having as consequence the appearance and development of some consumption patterns visible at the macroeconomic scale. The new tendencies of consumer's behavior, basically based on the reconfiguration of their approaches and expectations, have their origin in the corroboration of new sustainable economy's needs with the advances in digital technologies. The empowering of consumers squeezes out of the emergence of their online communities and of the online intellectual capital. The newest social aggregations of online type allow deepened transformations in actual society, starting from the need of an enhanced communication and flows of information on products of the digital markets which are bio-labelled [36].

Economic growth in modern era is no more related to the growth limits, growth opportunities being far way more important. The last ones are basically involving the developing knowledge, research investments, innovative trends and performance of technology, all known as smart economic growth. On the other hand, sustainable economic growth is based on green energy, policies involving low-carbon emissions and high reduction of collateral effects on environment. There exists important global interdependencies between economic growth, circular economy and the newest trend represented by intellectual capital. All of them when discussing the bio-economy advances. The regression models used to study such interdependencies are including various variables. Thus, the performance of innovation might be quantified using as proxy variable the number of patents. Circular economy would be measured using as dependent variable the added value. Intangible (knowledge/intellectual capital) and renewable resources used in a cascade are highly influencing the sensitivity of economic growth, in turn quantified using the gross domestic product. The intellectual property turned into patents is deepened influenced by the amount of the allocated funds for research and development, as well as by the fiscal freedom. When focusing on added value created in circular economy, there was found an important correlation with the export of recyclable raw material, employment of population in such domain as well as with the rate of the recycling of municipal waste Remarkable is the observed fact that the economic growth in the EU region is positively correlated with the productivity of employees from bio-economy domains [37].

Intangible capital is the structural capital (copyright, software, patents, know-how, etc.), human capital (employee skills and knowledge) and relational capital (brands, market segments, distribution channels / value chains). 
In the literature, the link between bioeconomics and intellectual capital takes into account human capital because the most valuable assets for achieving a bioeconomy are the knowledge, skills and experiences of professionals [38].

Thus, for defining the structural capital we have chosen the variable: patent application to the European patent office and for structural capital we chose turnover from innovation as a percentage of total. Wanting to contribute to the enrichment of the specialized literature we have proposed another independent variable, namely Stock market capitalization of bitcoin.

The analysis was done for the countries: Bulgaria, Czech Republic, Denmark, Estonia, Ireland, Greece, Croatia, Cyprus, Latvia, Lithuania, Luxembourg, Hungary, Malta, Austria, Portugal, Slovenia, Slovakia, Finland, Sweden, Iceland, Norway, Montenegro, Former Yugoslav Republic of Macedonia, Albania, Serbia and Bosnia and Herzegovina. These countries were chosen because, from the sample analyzed, they have similar characteristics in terms of energy consumption and innovations.

Our analysis demonstrates that countries where the progress of bio-economy cannot be achieved without harness of intellectual capital are countries that have a low economic and sustainable development.

Intellectual capital is the currency of research and technology transfer today, especially in the form of patents. The creation of research clusters alongside bioeconomic innovation is conditioned by the existence of quality universities. Collaboration between institutions and the economy can increase the quality of innovation. The opportunity and the mutual benefit of these collaborations is essential in order to bring real benefits.

The European Union has recognized universities as an essential resource for innovation by offering to support such activities. Risk Assessment, Design or Market Studies, Exploitation of Intellectual Property [39] are some of the actions being taken.

Romania has a great potential to develop an economy based on the concept of bio, because it is a country endowed with a wide variety of natural resources (forests, natural gas, fertile agricultural land $-7.5 \%$ of the agricultural area used in the EU - coal and lignite, crude oil, salt, minerals, silver, gold and hydrological networks).

The two-way link between universities, knowledge creators and the economic environment, the knowledge user and the resource generator can be synthesized from the perspective of the development of the Romanian bioeconomy in different ways: transfer of knowledge to companies or experimental functional research for products, technologies, methods, services, as well as significant improvement in the fields of intelligent specialization [41-42].

Bioeconomy should be strongly based on academic research. A strong academic environment can guarantee the existence and management of the resources needed for complex, laborious and expensive research, development and implementation. Starting from these arguments transposed in the context of Europe and Romania, the article supports the idea that the relationship between intellectual capital and bioeconomy is the key to progress in the field.

Starting from these arguments transposed into the context of Romania, the article supports the idea that intellectual capital-bioeconomy is the key to progress in the field, which cannot be achieved without sustained academic research. 


\section{Conclusions}

The intellectual capital of an organization can be successfully exploited through appropriate management strategies, these influencing the transformation of the intellectual capital potential (resources available) into the operational intellectual capital (results that increase the value of the organization). The benefits of optimal management of an organization's intellectual capital are numerous and generate an irreversible evolution on the scale of knowledge. Because the field of bioeconomics is a new and extremely complex one, it requires an advanced knowledge base on different niches.

The global crisis characterized by the crisis of the energy, ecology and the biosphere, and the environment requires solving the economic problem, satisfying a growing set of needs, given the limited and insufficient resources.

Bio-economy must be the basis for all economic activities and unlimited economic growth must be compatible with the fundamental laws of nature.

The results of our analysis showed that, in a knowledge-based economy, the link between sustainable bioeconomy and companies is achieved by Intellectual Capital. The intangible assets of Intellectual Capital coming from the external environment of a company in the shape of Relational Capital have great value, as they can offer competitive advantages. At European level, between bioeconomy and the turnover from innovation as a percentage of the total turnover, there is a strong direct link, the value of the correlation coefficient is equal to 0.954 . The second variable that influences bioeconomics is the variable proposed by us, namely Market Capitalization of Bitcoin. At Romanian level the bioeconomy is influenced most by the number of Patent applications to the European Patent Office in proportion of $81 \%$. Just as in the case of the European Union, also for Romania the indicator proposed by us influences the bioeconomy.

The results of our analysis lead to the conclusion that research and innovation play an important role in the evolution of bioeconomy both at European level and at the level of Romania.

Significant potential for bio-resources could be exploited through bioeconomic approaches. In order to achieve this capitalization, new solutions are needed for the sustainable intensification of the production of biological resources and for intelligent exploitation of bio-resources.

However, the practical development and implementation of these new solutions implies a significant investment in education and research, bioeconomic branches with high added value, meanwhile being branches of the knowledge-based economy.

We believe that the progress of bio-economy cannot be achieved without the harness of intellectual capital.

The contribution of this paper to the literature is:

- dividing countries by categories with similar characteristics in terms of innovation and energy consumption;

- inclusion of the Bitcoin variable in the analysis besides the variables included in the literature

- proposing to support the research activity of universities as a solution for the development of bioeconomy.

The analysis leaves room for further interpretations and future research because the study was only conducted for a period of 3 years and the number of variables was limited. 


\section{Author Contributions}

Conceptualization, Irina Chiriac; Data curation, Irina Chiriac; Formal analysis, Gabriela Ignat, George Ungureanu and Dragos Alexandru Robu; Methodology, Irina Chiriac; Project administration, Carmen Luiza Costuleanu; Supervision, Carmen Luiza Costuleanu; Validation, Gabriela Ignat, George Ungureanu, Dragos Alexandru Robu and Carmen Luiza Costuleanu; Visualization, Irina Chiriac, Gabriela Ignat, George Ungureanu, Dragos Alexandru Robu and Carmen Luiza Costuleanu; Writing - original draft, Irina Chiriac; Writing - review \& editing, Irina Chiriac, Gabriela Ignat, George Ungureanu, Dragos Alexandru Robu and Carmen Luiza Costuleanu.

\section{Funding}

This work was supported by a grant of the "Alexandru Ioan Cuza" University of Iasi, within the Research Grants program, Grant UAIC, code GI-UAIC-2018-05.

\section{Conflicts of Interest}

The authors declare no conflict of interest.

\section{References}

1. Manrique, S., Marti-Ballester, C.P., 2017, Analyzing the effect of corporate environmental performance in developed and developing countries. Sustainability, 9, 1957, DOI: 10.3390/su9111957.

2. Pîrvu, R., Bădîrcea, R., Manta, A., Lupăncescu, M., 2018, The effects of the cohesion policy on the sustainable development of the development regions in Romania. Sustainability, 10, 2577, DOI: 10.3390/su10072577.

3. Ross, D.G., 2013, Common Topics and Commonplaces of environmental rhetoric. Writ. Commun. 30, 91-131, DOI: 10.1177/0741088312465376.

4. Popa, J.C., Stan, N.S., 2017, Conceptual interferences of eco-bioethics on biodiversity and biosecurity. International legal instruments. Universul Juridic , pp.94-105.

5. Bonaiuti, M., 2015, Bioeconomics. In Degrowth: A vocabulary for a new era; D'Alisa, G., Demaria, F., Kallis, G., Eds.; Routledge/Taylor \& Francis Group: New York, London, pp. 25-28, ISBN 9781-138-00076-6.

6. Georgescu-Roegen, N., 1977, Bioeconomics: a new look at the nature of the economic activity. In The political economy of food and energy; Junker, L., Ed.; Ann Arbor, MI: University of Michigan, pp. 105-134.

7. Enriquez, J., 1998, Genomics and the World's Economy, Science, 281, 925-926, DOI: 10.1126/ science.281.5379.925.

8. Patermann, C., Aguilar, A., 2018, The origins of the bioeconomy in the European Union. New Biotechnol., 40, 20-24, DOI: 10.1016/j.nbt.2017.04.002.

9. Preda, N.I., Rîndaşu, S.M., 2013, Importance of intellectual capital for company development. CIG ASE Communication Session, Bucharest, Romania, pp. 1-23.

10. Juneja, J.A.; Amar, A.D., 2018, An organizational capital decision model for knowledge-intensive organizations. IEEE T. Eng. Manage, 65, 417-433, DOI: 10.1109/TEM.2018.2790898.

11. Pop, N., Valeriu, I.F., 2015, Crisis, globalisation, global currency. Procedia Economics and Finance, 22, pp.479-484.

12. D'Amato, D., Droste, N., Allen, B., Kettunen, M., Lahtinen, K., Korhonen, J., Leskinen, P., Matthies, B.D., and Toppinen, A., 2017. Green, circular, bio economy: a comparative analysis of sustainability avenues. Journal of Cleaner Production, pp. 716-734.

13. Meyer, R., 2017. Bioeconomy Strategies: Contexts, Visions, Guiding Implementation Principles and Resulting Debates. Sustainability, 9, pp. 1031-1064.

14. Staffas, L., Gustavsson, M., McCormick, K., 2013, Strategies And Policies For The Bioeconomy And Bio-Based Economy: An Analysis Of Official National Approaches. Sustainability, 5, pp.2751-2769. 
15. Birner, R., 2018. Bioeconomy concepts. In: I. Lewandowski, Bioeconomy. Shaping the transition to a sustainable, biobased economy. Cham: Springer.

16. Satler, A., Martin, B., 2001, The economic benefits of publicly funded basic research. Research Policy, 30(3), pp.509-532.

17. Krauss, J., Kuttenkeuler, D., 2018, Intellectual property rights derived from academic research and their role in the modern bioeconomy - A guide for scientists. New Biotechnology, 40(1), pp.133-139.

18. van Weenen, H., 2000, Towards a vision of a sustainable university. International Journal of Sustainability in Higher Education, 1(1), pp.20-34.

19. Dumay, J., 2009, Intelectual capital measurement: a critical approach. Journal of Intellectual Capital, 10(2), pp.190-210.

20. Edvinsson, L.; Malone, M., 1997, Intellectual Capital. Judy Piatkus Publishers, London

21. Toffler, A., 1995. Puterea în mişcare. Bucureşti: Antet.

22. Van de Vall, M. and Bolas, C., 1982, Using social policy research for reducing social problems: An empirical analysis of structure and functions. The Journal of applied behavioral science, 18(1), pp. 49-67.

23. Boljanovic, J.D., Dobrijević, G., Cerovic, S., Alcakovic, S., Djokovic, F., 2018, Knowledge-based bioeconomy: The use of intellectual capital in food industry of Serbia, Amfiteatru Economic, pp. 717-731

24. Bratianu, C. and Bejinaru, R., 2017, Knowledge strategies for increasing IC of universities. In Lopez I.T. \& Serrasqueiro, R. (Eds.). Proceedings of the 9th European Conference on Intellectual Capital, Instituto Universitario de Lisboa, Lisbon, Portugal, pp. 34-41.

25. Gârdan, D.A., Andronie, M., Gârdan, I.P., Iatagan, M., Hurloiu, I., 2018, Bioeconomy development and using of intellectual capital for the creation of competitive advantages by Smes in the field of biotechnology, Amfiteatru Economic, pp. 947-666

26. Anghel, I., Siminică, M., Cristea, M., Sichigea, M., Noja, G.G. 2018, Intellectual capital and financial performance of biotech companies in the pharmaceutical industry, Amfiteatru Economic, pp. 631-646

27. Nicolescu, O., Nicolescu, C., 2011, Organizaţia şi managementul bazate pe cunoştinţe. Bucureşti: Pro Universitaria.

28. EUROSTAT. Archive: Consumption of energy. Available Online: https://ec.europa.eu/eurostat/ statistics-explained/index.php/Consumption of energy (accessed on 01 October 2018).

29. CRYPTOCURRENCY, Available Online: https://www.coinbase.com/ (accessed on 01 October 2018).

30. EUROSTAT. Patent applications to the European Patent Office (source: EPO). Available Online: https://ec.europa.eu/eurostat/tgm/table.do?tab=table\&init=1\&plugin $=1 \&$ language=en\&pcode $=\mathrm{S}$ dg 0940 (accessed on 01 October 2018).

31. EUROSTAT. Turnover from innovation. Available Online: https://rio.jrc.ec.europa.eu/en/stats/ turnover-innovation (accessed on 01 October 2018).

32. BOR. Bioeconomy policies and strategies established by 2017. Diagram prepared by the German Bioeconomy Council (Biookonomierat - BOR), Berlin. Available Online: http://biooekono mierat.de/home-en.html (accessed on 01 October 2018).

33. ELSEVIER. Scopus bibliographic database. Available Online: https://www.elsevier.com/ solutions/scopus (accessed on 01 October 2018).

34. Edvinsson, L., Malone, M., 1997, Intellectual Capital. Judy Piatkus Publishers, London.

35. Rotta, T.N., 2018, Unproductive accumulation in the USA: a new analytical framework. Camb. J. Econ, 42, 1367-1392, DOI: 10.1093/cje/bex080

36. Vătămănescu, E.M., Alexandru, V.A., Cristea, G., Radu, L., Chirica, O., 2018, A demand-side perspective of bioeconomy: The influence of online intellectual capital on consumption. Amfiteatru Econ, 20, 536-552, DOI: 10.24818/EA/2018/49/536. 
37. Nedelea, A.M., Mironiuc, M., Huian, M.C., Bîrsan, M., Bedrule-Grigoruța, M.V., 2018, Modeled inter-dependencies between intellectual capital, circular economy and economic growth in the context of bioeconomy. Amfiteatru Econ. 20, 616-630, DOI: 10.24818/EA/2018/49/616.

38. Peng, T.J.A., Pike, S., Roos, G., 2007, Intellectual capital and performance indicators: Taiwanese healthcare sector. Journal of Intellect Capital, 8(3), pp. 538-56

39. Kuttenkeuler, D., 2018, A guide for scientists. New Biotechnology, pp.143-144.

40. De Bartolo, A., 1999, Modern human capital analysis: estimation of US, Canada and Italy earning functions, Working Paper no. 212; Maxwell School of Citizenship and Public Affairs Syracuse University, Syracuse, New York, 1999; pp.1-16. Available Online: https://pdfs.semantic scholar.org/c771/e6d2e4097bfed67564db8e6e341f24dd0a7b.pdf (accessed on 01 October 2018).

41. European Commission, 2012, Innovating for Sustainable Growth, A Bioeconomy for European, Available online: https://ec.europa.eu/research/bioeconomy/pdf/201202 innovating sustainable growth en.pdf (accessed on 01 October 2018).

42. OECD, 2009, The bioeconomy to 2030. Designing a policy agenda. Main findings and conclusions. Organisation for Economic Co-operation and Development. Available online: https://www.oecd.org/futures/long-termtechnologicalsocietalchallenges/42837897 (accessed 1 octombrie 2018). 